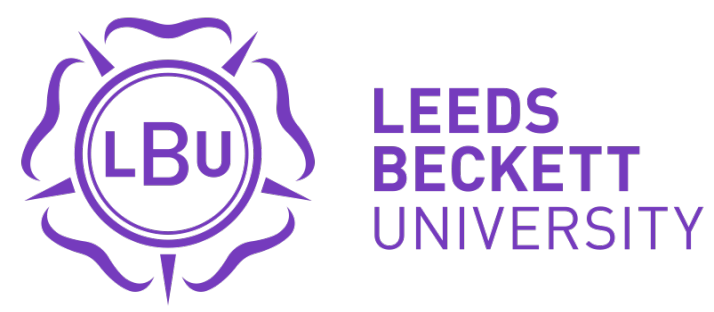

Citation:

Lashua, BD (2018) Popular Music Heritage and Tourism. In: The Routledge Companion to Popular Music History and Heritage. Routledge, London, pp. 153-162. ISBN 978-1-138-23763-6

Link to Leeds Beckett Repository record:

https://eprints.leedsbeckett.ac.uk/id/eprint/5564/

Document Version:

Book Section (Published Version)

The aim of the Leeds Beckett Repository is to provide open access to our research, as required by funder policies and permitted by publishers and copyright law.

The Leeds Beckett repository holds a wide range of publications, each of which has been checked for copyright and the relevant embargo period has been applied by the Research Services team.

We operate on a standard take-down policy. If you are the author or publisher of an output and you would like it removed from the repository, please contact us and we will investigate on a case-by-case basis.

Each thesis in the repository has been cleared where necessary by the author for third party copyright. If you would like a thesis to be removed from the repository or believe there is an issue with copyright, please contact us on openaccess@leedsbeckett.ac.uk and we will investigate on a case-by-case basis. 


\section{Popular music heritage and tourism}

Brett D. Lashua

[Lashua, B.D. (2018) Popular music tourism and heritage. In S. Baker, L. Istvandity, C. Strong, and Z. Cantillon (Eds.) The Routledge Companion to Popular Music History and Heritage. London: Routledge (pp. 153-162).]

\section{Introduction}

Where music and musicians have travelled, tourists often travel too, visiting the various traces left behind. In 2011, UK Music CEO Feargal Sharkey asked: 'Is there anything else, other than music that has the power to transform the utterly mundane, like a pedestrian crossing in north London, into an international tourist hotspot?' (UK Music 2011, p. 2). This chapter explores the 'power to transform' in the relations between popular music, heritage and tourism.

After brief excursions into the literature on music tourism and music heritage, this chapter visits two differing discourses of heritage produced through popular music tourism; in turn, it excavates where, and how, tourism has (re)produced heritage. First, the chapter examines the fabrication of popular music heritage in Winslow, Arizona. Briefly mentioned in the lyrics of the Eagles' song 'Take it easy' (1972), Winslow annually attracts over 100,000 people who visit a statue, mural, and festival at the 'Standin' on a Corner Park', even though the Eagles had never been there. In the case of Winslow, popular music tourism has flourished through processes of self-authorised or 'inauthentic' popular music heritage.

Second, I consider official, authorised, 'authentic' and (often) tangible heritage (Smith 2006) in museums as tourism attractions. The chapter spotlights the Rock and Roll Hall of Fame and Museum in Cleveland, Ohio, a spectacular building in a somewhat unspectacular tourism destination. In addition to its presence as an anchor in the cultural and economic regeneration of Cleveland, I highlight the heritage discourse that underpins the city's claim to be the museum's host site. This discourse both celebrates and masks the story of the 'Moondog Coronation Ball' of 21 March 1952, acclaimed as the first ever rock ' $n$ ' roll concert (Gillett 1970).

These two music tourism case studies are set in juxtaposition to help evaluate the construction of authorised, self-authorised and unauthorised heritages (Roberts and Cohen 
2014) through popular music tourism. In doing so, music tourism is useful to explore questions posed by Cohen et al. (2014, p. 1, original emphasis): 'what is popular music heritage?; where is it located?; why does it matter?; whose popular music heritage? and when does popular music become heritage?' In this sense, music tourism can help conceptualise music heritage, and vice versa, music heritage allows purchase on debates about music tourism.

\section{Music tourism}

There is a growing body of music and tourism scholarship (e.g. Gibson and Connell 2005, Waitt and Duffy 2010, Kruger and Trandafoiu 2013, Lashua et al. 2014). Well beyond the famous pedestrian crossing outside Abbey Road studios, tourist destinations for popular music heritage crop up in myriad locations where music-making once took place or musicians passed by. These range from 'places of performance' (Gibson and Connell 2007, p. 164) including venues such as the Cavern Club in Liverpool (Kruse 2005) and Ryman Auditorium in Nashville (Pecknold 2014), to recording facilities as 'places of production' (Gibson and Connell 2007, p. 164) such as Sun Studios in Memphis (Rushing 2014). Beyond landmark buildings, some now-iconic attractions were incidental sites featured on album artwork, e.g. the telephone booth appearing on The Rise and Fall of Ziggy Stardust and the Spiders from Mars (1972) off London's Heddon Street, or the shop at Ludlow and Rivington Streets featured on the album artwork for the Beastie Boys' Paul's Boutique (1989). There is something both proximal and elusive in visiting these sites, a desire to be as close to the artists and musical moments as the past allows. Yet heritage is also laden with questions and contestations, particularly regarding decisions about what constitutes heritage, whose heritage is celebrated and which is unacknowledged.

If heritage is conceptually challenging terrain when coupled with popular music (Roberts and Cohen 2014), it becomes more complex with tourism added into the mix. Some tourists seek to explore the footprints of music heritage in places where it has been largely erased, hidden or ignored (Long 2014). Other heritage landmarks are 'at risk' (Cohen 2007): underappreciated, neglected, demolished (e.g. Liverpool's original Cavern Club) or dramatically changed. Tourism, in combination with heritage, has resurrected some of these places, or helped preserve them. Other music and tourism studies, notably the work of John Connell and Chris Gibson, move betwixt and between sites both familiar and unusual, for example, from Elvis' home at Graceland, to the Parkes Elvis Festival in Australia (Gibson 
and Connell 2007, Connell and Gibson 2014). Different music attractions produce different heritages, just as differing heritages produce tourist experiences.

There are also differences in how music heritage tourism is valued, as it has become increasingly culturally and economically significant. Economically, a UK Music report (2016) celebrated that over 10 million music tourists spent more than $£ 2$ billion visiting the UK in 2015. In 'music cities' such as Liverpool, Memphis, Nashville and others, music tourism is seen as an engine of economic development or regeneration (Cohen 2007). During Liverpool's tenure as 2008 European Capital of Culture, the city celebrated its renaissance built largely upon the promotion of its popular music heritage (Lashua et al. 2010). The city reported '9.7 million additional visits to Liverpool' and 'a $34 \%$ rise on the previous year' with an 'economic impact of $£ 753.8$ million (additional direct visitor spend) across Liverpool, Merseyside and the wider North West region' (Garcia et al. 2010, p. 3). Yet, economic impacts are often overshadowed by the music tourism's cultural significance.

Music tourism is a 'distinctive component' of cultural tourism 'in various ways, appropriating myths of place, transforming localities materially and discursively, thus supporting tourist development' (Gibson and Connell 2005, p. 14). Music tourism connects with heritage in terms of 'authenticity' (or 'accuracy'). Tourism to authentic music places can be seen as 'quests for roots' (Gibson and Connell 2007, p. 161) or nostalgia (Greig and Strong 2014). This is evident in visits to musician's childhood homes, venues where musicians performed, studios where they recorded, and so on. As leisure, music heritage tourism includes a search for fun and enjoyment in visiting these places, but it is far from frivolous: 'it goes beyond the trivial ... through connections to complex cultural issues - of authenticity, essentialism, and heritage' (Gibson and Connell 2005, p. 17). Music heritage provides 'an important and emotive narrative for tourists, as an expression of culture, a form of heritage, a signifier of place and a marker of moments' (Lashua et al. 2014, p. 3).

\section{Popular music heritages}

This chapter presents touristic case studies that spotlight challenging and contested meanings, sites, and constructions of heritage. For Smith (2006, p. 1):

heritage wasn't only about the past - though it was that too - it also wasn't just about material things - though it was that as well - heritage was a process of engagement, an 
act of communication and an act of making meaning in and for the present.

While often intangible, heritage matters as 'memory and remembering, performance, place, and dissonance' (Smith 2006, p. 3). It offers a resource to negotiate or contest cultural meanings, values and identity constructions (Smith 2006). In this, heritage becomes an active process - a verb: to heritage. As Smith (2006, p. 4) notes, heritage has fluidity and changeability, it is as much about preserving the past as 'reworking the meanings of the past as the cultural, social and political needs of the present change and develop'. Heritage, then, is a discourse, loaded with social and political power.

Drawing these ideas together, Smith identifies 'authorized heritage discourses' (AHD) that circumscribe tangible, monumental, grand, and ideologically designated 'good' heritage. AHD work 'to naturalize a range of assumptions about the nature and meaning of heritage' (Smith 2006, p. 4) through formal eligibility criteria and selection processes via established, institutional peer ('expert') decision-making. As such, AHD produce an aura of inevitability in particular heritage narratives at the expense of other stories and cultural meanings that become hidden, invisible or unremarked. Most visible in museums (Leonard 2013) and 'official' tourist attractions and destinations, AHD become the story of a particular heritage. Examples of AHD in popular music heritage tourism are manifest in museums that celebrate the music of ABBA in Stockholm, Graceland in Memphis, and 'The Beatles Story' in Liverpool as well as the 'Magical Mystery Tour' that transports tourists around that city tracing physical sites of Beatles heritage (see Gibson and Connell 2005, pp. 48-50). These museums and tours not only represent an official heritage, they produce it.

Alongside Smith's concept of authorised heritage, Roberts and Cohen (2014) add selfauthorised and unauthorised popular music heritages. Although there is potential interrelation with official heritage discourses, self-authorised heritages are described as often intangible, without formal selection criteria, with public groups involved in local, democratic processes of authorisation. Lastly, unauthorised, counter- or anti-heritage discourses can resist or contravene AHD, such as Graves-Brown and Schofield's (2011) archaeological treatment of the Sex Pistols' graffiti at 6 Denmark Street, London. They championed a punk anti-heritage set against authorised discourses of music and art.

\section{Why was my dad a-standin' on a corner in Winslow, Arizona?}


This section presents a case study of popular music heritage tourism at the intersection of a historic road - Route 66 - and a fictional heritage based on a 'throwaway line' (Bunacombe 2015, para. 3) in song lyrics. Gibson and Connell (2007, p. 164) refer to this as a type of music tourism built on 'lyrical places' such as 'Mull of Kintyre, Mountains of Mourne; Girl from Ipanema; Route 66'. Along similar lines, Darvill (2014, p. 462) notes the construction of popular music heritage 'in relation to three discernible kinds of place-production' including:

linear places epitomized by roads and routes such as Highway 61 and Route 66; dispersed places represented by memorial plaques and statues on buildings and in open spaces; and concentrations of connected elements such as can be found in Liverpool (UK) and Memphis (USA).

This case connects these three 'kinds' of place-production.

My father made regular transcontinental tours across the USA on his Harley-Davidson motorcycle. After one trek, my dad sent me an unusual photo. His normal imagery - a 'selfie' taken while cruising, an epic Western landscape, or his beloved Harley - shifted focus in just one shot, showing him, dismounted, in a 'landmark' location. Somewhat gruff, I suppose, he avoided crowds and detours to tourist attractions, except in one photograph he sent to me following a stop in Winslow, Arizona.

Winslow lies along Route 66, the highway immortalised in the 1946 song by Bobby Troupe '(Get your kicks on) Route 66' ${ }^{1}$. Route 66 was an early continuous road, over 2000 miles long, between Chicago and Los Angeles. As Gibson and Connell (2005, p. 179) note, 'no other road in the United States is as famous as Route 66; no other road has become part of the national culture and mythology, or as treasured in memory'. Enshrined by author John Steinbeck as 'the mother road' in The Grapes of Wrath (1939), and Beat author Jack Kerouac in On The Road (1957), Route 66 'came to symbolize freedom, excitement and endless promising horizons' (Gibson and Connell 2005, p. 179). The heritage of Route 66 is built on patriotic American themes of Western expansion and manifest destiny, automobile culture and the open road, an escape from rusting northeastern industries to the sunshine and potential prosperity in the West.

Although Troupe's song doesn't mention Winslow, when created in 1926 Route 66 already served as Winslow's Main Street. Indeed, as it ran through so many towns along its circuitous 
path, Route 66 was nicknamed 'America's Main Street'. Route 66's traffic was the life's blood of Winslow until Interstate 40 bypassed the town in 1979. With the loss of its main traffic artery, local businesses suffered, and the town withered.

While historic Route 66 has since become a major tourist attraction, Winslow has another claim to popular music fame. The town was mentioned in the lyrics to the Eagles' hit song 'Take it easy' (1972), ${ }^{2}$ written by musician Jackson Browne and the Eagles' Glenn Fry. The song's second verse describes standing on a street corner in Winslow, Arizona while watching, and being watched by, a woman driving by in a Ford pick-up truck. Neither the Eagles, nor Jackson Browne for that matter, had ever visited Winslow. My dad did, although not an Eagles fan, and there he was in a photo, standing on the corner in Winslow, Arizona.

Although lacking claims to authenticity beyond these lyrics, in 1999 Winslow officials installed a statue of a man with a guitar at the corner of 2 nd Street and Kinsley Street. 'Locals credit the official who hit upon the idea of trying to cash in on the town's quiet celebrity' (Bunacombe 2015, para. 6) while one local historian offered: 'People were stopping and taking pictures on corners in Winslow anyway. So they were quite brilliant to realise that they should capitalise on this interest' (Bunacombe 2015, para. 7). A mural was added, and the immediate area became 'Standin' on the Corner Park'. Winslow soon began hosting an annual 'Standing on the corner' music festival (2016 was its 18th year) bringing 5,00010,000 visitors for a weekend of music (and Eagles cover bands). In September 2016 another statue was added to the park with the likeness of the late Glenn Fry. According to one Winslow city official, in recent years, the town with a population of no more than 10,000 , has seen something of a renaissance, all thanks to a throwaway line in a song that [has] become one of rock music's more popular anthems' (Buncombe 2015, para. 3).

Standin' on the Corner Park is thus an example of self-authorised popular music heritage (Roberts and Cohen 2014, p. 248), one of 'many DIY, localized or vernacular popular music heritage discourses' that are often more participatory or 'democratic' than AHD. According to one news report, 'Standin' on the Corner Park was built brick by brick with donations made by local businesses, individuals, many volunteer hours and investments by the city of Winslow' (Locke 2016, para. 15). Locals donated the land, painted the park's mural, and made the bronze 'Rock and Roll guitarist' statue 'placed over personalized donor bricks' (Locke 2016, para. 15). Although self-authorised by locals, such practices nonetheless often 
make "claims to (or solicitations of) some form of official status [which] may invariably play an important role in terms of marketing and publicity, or ensuring the sustainability and development of the heritage initiative or resource in question' (Roberts and Cohen 2014, p. 248). In this case, the recently installed statue of Glenn Fry demonstrates an interrelated 'official' discourse alongside the self-authorised heritage of the park; songwriter Jackson Browne also officially commented on the intentionality of naming Winslow in the song, stating 'it was always Winslow' (Bunacombe 2015, para. 9).

This mini-case study of Winslow also echoes accounts of the Parkes (Australia) Elvis Festival (Mackellar 2009, Connell and Gibson 2014) where a heritage music festival has flourished in the absence of an official heritage: Elvis Presley never visited Parkes, yet tourism has grown there in 'response to declining economic conditions in the rural town' (Mackellar 2009, p. 8). As in Parkes, music tourism is a considerable part of the cultural economy in Winslow, like other sites where 'cultural tourism has enabled the revitalisation of declining city centres or industrial towns' (Gibson and Connell 2005, p. 13), although often with varying degrees of 'success' and sustainability.

Winslow's case study allows responses to the questions asked by Cohen et al. (2014, p. 1): 'what is popular music heritage?; where is it located?; why does it matter?' The selfauthorised popular music heritage of Winslow is centered on tourism as an intended outcome of 'place-production' (Darvill 2014) built around the town's links to Route 66 and lyrics in an Eagles' song. Its self-authorised heritage has become manifest in a park, mural, festival, statues, and associated tourism industries (e.g. hotels, restaurants, and other services). The director of Winslow's Old Trail Museum remarked: 'Whether you like the song or not, whether you like Winslow or not, you're going to take a picture of the corner' (Bunacombe 2015, para. 7). Even my dad did.

\section{Cleveland rocks? Locating the Rock and Roll Hall of Fame and Museum}

I am originally from the Cleveland, Ohio area, where I played drums in rock bands from the late 1980s through the early 2000s. I remember when, in 1986, following a 'groundswell of public support and a \$65 million commitment from city officials’ (Rock Hall n.d., para. 1) Cleveland had been chosen as site of the future Rock and Roll Hall of Fame and Museum, beating New York, San Francisco, Memphis and Chicago. 
Cleveland was awarded the rights to build the Rock Hall after local officials touted the city's role in the history of rock ' $n$ ' roll. In 1996, a year after the museum opened its doors, I performed on the plaza in front of the Hall, during its 'Summer in the City' concert series. Even then I didn't fully understand why Cleveland was chosen as the site of the Rock Hall. I knew little about the city's popular music heritage, beyond being aware of a handful of celebrated musicians from Northeastern Ohio - Screamin' Jay Hawkins, Pere Ubu, The Raspberries, Tracy Chapman, The O'Jay's, Chrissie Hynde, Devo, and a handful of others many of whom were born in the area yet made their fame elsewhere. It did not seem to me that there were grounds for Cleveland to claim the 'birthplace of Rock ' $n$ ' Roll' tagline that appeared on signage around the city when the Rock Hall arrived. What supports this claim? What are its roots? Beyond these questions, would people wish to visit Cleveland - a postindustrial city on Lake Erie - as rock ' $n$ ' roll tourists?

Cleveland, as far as I knew, had no spectacular moments or scenes; there wasn't anything particularly 'authentic' about popular music in Cleveland; there was no distinctive 'Cleveland sound'. This presented a dissonance, in terms of popular music heritage, as Gibson and Connell (2007, p. 168) note:

In music tourism, much is made of the 'roots' of music in particular locations, eras and in social 'scenes' - the 'psychedelic' scene of San Francisco in the 1960s, jazz from New Orleans, waltzes from Vienna. Settings for the myths of classical music, rock ' $n$ ' roll, hip hop and other styles are made authentic through discussions of the places and people surrounding musical creativity and production.

Although Gibson and Connell (2007, p. 168) offered that some "places become known as authentic sites of musical creativity, where "musicians came together", and where the "magic of composition took place"", this didn't characterise Cleveland either. However, there was another story I didn't yet know.

In the 1950s, Cleveland was seen as break out city for new popular music (Adams 2002) While, nationally, a handful of radio DJs were playing R\&B 'race' records on a few stations, Adams (2002, p. 5) described Alan Freed (1921-1965) as 'the first white radio man to do so on the North Coast'. Arriving in Cleveland in 1950, Freed began broadcasting on local station WJW in July 1951, hosting a classical program in the evenings followed by a late night slot from 11.15 p.m. to 2 a.m. Due to these moonlit hours, Freed called his late program 'The Moondog Show'. Sponsored by a local record store, Record Rendezvous, and its owner Leo 
Mintz, Freed would later recall that he and Mintz used (rather than coined) the phrase 'rock ' $n$ ' roll' to avoid the 'racial stigma' of rhythm and blues (Irwin 1957, p. 60). 'Freed appended the phrase "rock \& roll" to black rhythm and blues', according to Jackson (1991 p. i, emphasis added). As this music 'caught on with the growing white audience that enjoyed the luxury of money to burn and time to kill, Freed quickly realized he was positioned to become rock \& roll's first prominent spokesperson' (Jackson 1991, p. 1).

Building on his Moondog radio show, Freed and Mintz organised what some view as the first rock ' $n$ ' roll concert, the 'Moondog Coronation Ball', 21 March 1952 (Gillett 1970, Jackson 1991, Adams 2002). Capitalising on Freed's radio popularity, the Moondog Coronation Ball would celebrate rock ' $n$ ' roll and crown Freed as the 'king of the moondoggers'. Rebelliously advertised as 'the most terrible ball of them all' to appeal to its teenage audience, the concert featured Paul Williams and the Hucklebuckers, Tiny Grimes \& the Rockin' Highlanders, The Dominoes, Varetta Dillard, and others. On the night, over 16,000 people turned up at the 9,000-seat Cleveland Arena:

Neither Freed or the Arena staff were prepared for the large crowd that showed up the night of the concert. After admitting the capacity of the hall, there were still thousands outside waiting to get in. When the music started, the huge crowd outside broke down the Arena doors. Inside, fighting broke out in, the audience and the concert ended after the first song. It took the Cleveland Police Department ... and Fire Department several hours to clear the Arena and to stop the fighting. (Halasa 2009, para. 5)

This event is remembered less as a concert and more as a race riot, as the police dispersed the angry and largely black crowds (Gillett 1970, Adams 2002, Burgoyne 2003). The local press sensationalised the event, presaging the 'moral panics' that characterised responses to later youth subcultures. Although his show's popularity soared, Freed was accused of purposely overselling the show and endangering the audience. Local newspapers 'gave the incident front page coverage and the wire service spread the story around the world. Suddenly, the press was talking about rock ' $n$ ' roll and its evils' (Halasa 2009, para. 5). Despite attempts by local authorities to regulate these events, Freed and Mintz went on to host several Moondog concerts (with reserved seating) in Northeast Ohio that year, e.g. 20 June 1952 in Akron; 4 October 1952 in Youngstown; and 18 October 1952 in Canton. Having created a popular radio show and concert series, Freed closed out his Cleveland career with a 1953 concert showcasing Fats Domino, The Drifters, The Moonglows, The Harptones, the Buddy Johnson Orchestra, Big Joe Turner and others, before moving in 1954 to a bigger market, and bigger 
controversies, in New York City.

How then, did this heritage provide the basis for the establishment of the Rock and Roll Hall of Fame and Museum in Cleveland? Reviewing Gillett's (1970) landmark book, one Cleveland journalist expressed bemusement: 'Remember Alan Freed, the King of the Moondogs? Brace yourself for this: He may have been a significant figure in American musical history' (McGunagle 1971, p. 3). In 1972, local radio producer Billy Bass of WMMS, began calling Cleveland 'the rock ' $n$ ' roll capital of the world' (Halasa 2009, para. 9). This became Cleveland's campaign slogan during the competition to become the host city for the Rock Hall in the mid-1980s. As part of this campaign, another Cleveland radio DJ, Norm N. Nite, mobilised the legacy of Freed and the Moondog Coronation Ball as part of Cleveland's (ultimately successful) bid. The story of this event, then, has become a cornerstone of a place myth which has transformed the city both 'materially and discursively, thus supporting tourist development' (Gibson and Connell 2005, p. 14).

Economically, tourist development in Cleveland is not insubstantial, where the Rock Hall has provided an anchor in the city's waterfront redevelopment along with a science center (1996) and stadium (1999). According to the Rock Hall's (n.d., para. 4) website:

Since opening in 1995, the Rock \& Roll Hall of Fame has welcomed more than 10 million visitors from around the globe and generated more than $\$ 2$ billion in economic impact for Northeast Ohio. In 2015, 500,000 people visited the Rock Hall, a figure which represents a $15 \%$ attendance bump from the year before. These visitors $90 \%$ of whom live outside of Cleveland - help the Rock Hall contribute \$107 million in annual economic impact to the region.

Upon its 20th anniversary, Uyricki (2015) noted that in its first year the Rock Hall drew 870,000 visitors. While this number dropped to less than half of that figure 10 years later, a further 10 years on visitor numbers have increased. In 2013, attendance was 441,290, and the Rock Hall celebrated its 10 millionth visitor in 2015 (Uyricki 2015). The attention brought to the city in terms of tourism generation was described by Rock Hall president and CEO Greg Harris as 'a home-run for the local economy' (Uyricki 2015), which translates into an estimated economic impact of nearly $\$ 2$ billion to Northeast Ohio (Harris 2016).

Beyond this economic impact, what then of the cultural impact of the Rock and Roll Hall of Fame and Museum in Cleveland? Returning to some of the questions of popular music 
heritage posed by Cohen et al. $(2014$, p. 1) - what is it, and why does it matter? - part of the official heritage discourse in Cleveland was drawn from the desire to attract tourists to the city and help revitalise its economy. Another part of the authorised heritage discourse is built on mythic origins of the 'birthplace' of rock ' $n$ ' roll and presents a simplified, sanitised version of events: i.e., Cleveland hosted the first rock ' $n$ ' roll concert. In this regard, Gibson and Connell (2007, p. 165) commented, 'tourists thus collude in the evident staging and inauthenticity of particular sites because it enables some recognition and understanding of a sought-after order and simplicity (as at Graceland)'. The racialised relations in Cleveland are largely absent from the construction of its authorised popular music heritage discourses. Although Adams (2002) included interviews with those who had been in the audience or musicians at the event, few of the black artists on the original bill are recognised for being part of the event, and the stories of the black young people are largely absent within the dominant heritage frames centred on Freed. Stories of these musicians and concertgoers constitute a counter-heritage, or unheralded 'heritage from below' (Robertson 2016).

Since 1992, an annual Moondog Coronation Ball concert has been hosted by local 'oldies' radio station, WMJI. The most recent concert (1 April 2017) featured Tommy James and the Shondells, Grand Funk Railroad, and Three Dog Night. There were no reports of any riots.

\section{Conclusions}

This chapter has explored popular music heritage tourism though two brief case studies. One examined heritage constructed at a site - 'standin' on a corner in Winslow, Arizona' - with little authenticity; the other case traced the development of heritage discourse around the Rock and Roll Hall of Fame in Cleveland. Both showcase elements of authorised and selfauthorised heritage, as Roberts and Cohen (2014, p. 248) note:

it is important to emphasise the ambiguity of these categories. No matter how much authority is assumed through processes of self-validation, claims to (or solicitations of) some form of official status may invariably play an important role in terms of marketing and publicity, or ensuring the sustainability and development of the heritage initiative or resource in question. Official and self-authorised discourses may, thus, be closely interrelated and reaffirm or contradict one another.

Within the accounts popular music heritage and tourism in Winslow and Cleveland there is mix of authorised and self-authorised discourses, and potential for unauthorised or counterheritage. With both cases I have attempted to illustrate popular music heritage tourism as a 
product of complex layers of meanings, where the mobilisation of popular music heritage for cultural and economic tourism has 'the power to transform' (UK Music 2011, p. 2) even the unlikeliest of places.

\section{Acknowledgments}

Chapter content about Cleveland was supported by a research fellowship through Case Western Reserve University's Center for Popular Music Studies and the Rock and Roll Hall of Fame Library and Archives. I am grateful to Professor Daniel Goldmark at CPMS, and the brilliant archivists at the Rock Hall: Jennie Thomas, Andy Leach, Jona Whipple, Anastacia Karel, Sule Holder, Shannon Erb, and William Jackson.

\section{Notes}

\footnotetext{
${ }^{1}$ Recorded by Nat King Cole in 1946, then again in 1956 and 1961; versions of this song include covers by Chuck Berry (1961) and the Rolling Stones (1964).

${ }^{2}$ Released 1 May 1972, 'Take it easy' peaked at no. 12 on the US Billboard charts on 22 July 1972.
}

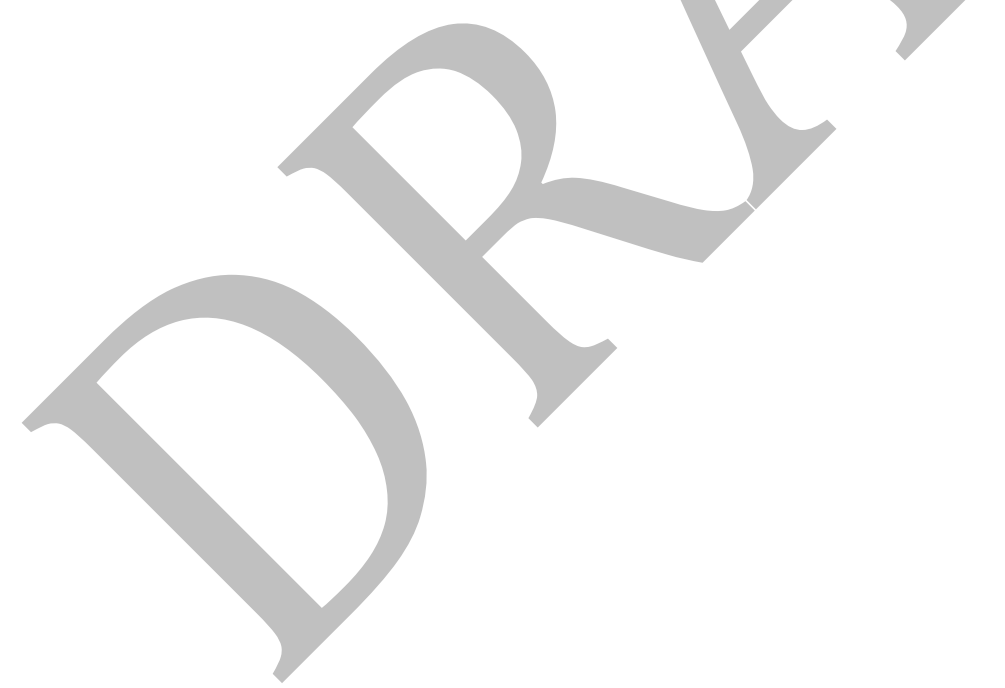




\section{References}

Adams, D.R., 2002. Rock ' $n$ ' roll and the Cleveland connection. Kent, OH: Kent State University Press.

Buncombe, A., 2015. 100,000 people travel every year to stand on a corner in Winslow, Arizona, and 'Take it Easy'. Independent [online]. Available from: http://www.independent.co.uk/news/world/americas/100000-people-travel-every-year-tostand-on-a-corner-in-winslow-arizona-and-take-it-easy-9988901.html [Accessed 1 April 2017].

Burgoyne, R., 2003. From contested to consensual memory: the rock and roll hall of fame and museum. In: K. Hodgkin and S. Radstone, eds. Contested pasts: the politics of memory. London: Routledge, 208-220.

Cohen, S., 2007. 'Rock landmark at risk': popular music, urban regeneration, and the built urban environment. Journal of Popular Music Studies, 19 (1), 3-25.'

Cohen, S., et al., eds., 2014. Sites of popular music heritage: memories, histories, places. London: Routledge.

Connell, J. and Gibson, C., 2014. Outback Elyis: musical creativity in rural Australia. In: B. Lashua, K. Spracklen, and S. Wagg, eds. Sounds and the city: popular music, place and globalization. Basingstoke: Palgrave Macmillan, 285-301.

Darvill, T., 2014. Rock and soul: humanizing heritage, memorializing music and producing places. World Archaeology, 46 (3), 462-476.

Garcia, B., Melville, R., and Cox, T., 2010. Creating an impact: Liverpool's experience as European Capital of Culture. Liverpool: University of Liverpool.

Gibson, C. and Connell, J., 2005. On the road again: music and tourism. Clevedon: Channel View Publications.

Gibson, C. and Connell, J., 2007. Music, tourism and the transformation of Memphis. 
Tourism Geographies, 9 (2), 160-190.

Gillett, C., 1970. The sound of the city: the rise of rock \& roll. New York: Outerbridge \& Dienstfrey.

Graves-Brown, P. and Schofield, J., 2011. The Filth and the fury: 6 Denmark Street (London) and the Sex Pistols. Antiquity, 85, 1385-1401.

Greig, A. and Strong, C., 2014. But we remember when we were young: Joy Division and New Orders of nostalgia. Volume! The French Journal of Popular Music, 11 (1), 192-205.

Halasa, J., 2009. Rock 'n' roll. The Encyclopedia of Cleveland History [online]. Available from: http://ech.case.edu/cgi/article.pl?id=RR [Accessed 1 April 2017].

Harris, G., 2016. Long live rock: the hall of fame comes of age [online]. Available from: https://cityclub.org/events/long-live-rock-the-hall-of-fame-comes-of-age [Accessed 1 April 2017].

Irwin, T., 1957. Rock 'n roll 'n Alan Freed. Pageant, July, pp. 56-63.

Jackson, J.A., 1991. Big beat heat: Alan Freed and the early years of rock \& roll. New York: Schirmer Books.

Kruger, S. and Trandafoiu, R., eds., 2013. The globalization of musics in transit: musical migration and tourism. London: Routledge.

Kruse, R.J., 2005. The Beatles as place makers: narrated landscapes in Liverpool, England. Journal of Cultural Geography, 22 (2), 87-114.

Lashua, B.D., Long, P., and Spracklen, K., 2014. Introduction: music and tourism. Tourist Studies, 14 (1), 3-9.

Lashua, B.D., Cohen, S., and Schofield, J., 2010. Popular music, mapping and the characterisation of Liverpool. Popular Music History, 4 (2), 127-146. 
Leonard, M., 2013. Staging the Beatles: ephemerality, materiality and the production of authenticity in the museum. International Journal of Heritage Studies, 20 (4), 357-375.

Locke, K., 2016. 18th annual Standin' on the Corner Fest Friday and Saturday. Navajo-Hopi Observer [online]. Available from: https://www.nhonews.com/news/2016/sep/20/18thannual-standin-corner-fest-friday-and-saturda/ [Accessed 1 April 2017].

Long, P., 2014. Popular music, psychogeography, place identity and tourism: the case of Sheffield. Tourist Studies, 14 (1), 48-65.

Mackellar, J., 2009. Dabblers, fans and fanatics: exploring behavioural segmentation at a special-interest event. Journal of Vacation Marketing, 15 (1), 5-24.

McGunagle, F., 1971. Mar. 21, 1952 - at the Cleveland Arena: the first rock festival. The Cleveland Plain Dealer, 5 February, p. 3.

Pecknold, D., 2014. Heart of the country? The construction of Nashville as the capital of Country Music. In: B. Lashua, K. Spracklen, and S. Wagg, eds. Sounds and the city: popular music, place and globalization. Basingstoke: Palgrave, 19-37.

Roberts, L. and Cohen, S., 2014. Unauthorising popular music heritage: outline of a critical framework. International Journal of Heritage Studies, 20 (3), 241-261.

Robertson, I.J., ed., 2016. Heritage from below. London: Routledge.

Rock and Roll Hall of Fame and Museum, n.d. About the Rock Hall [online]. Available from: https://www.rockhall.com/visit/about-rock-hall [Accessed 1 April 2017].

Rushing, W., 2014. We're going to Graceland: globalization and the reimagining of Memphis. In: B. Lashua, K. Spracklen, and S. Wagg, eds. Sounds and the city: popular music, place and globalization. Basingstoke: Palgrave, 258-272.

Smith, L., 2006. The uses of heritage. London: Routledge. 
UK Music, 2011. Destination music: the contribution of music festivals and major concerts to tourism in the UK. London: UK Music.

UK Music, 2016. Wish you were here 2016: music tourism's contribution to the UK economy. London: UK Music.

Uyricki, M., 2015. Rock and Roll Hall of Fame celebrates 20 years in Cleveland [online]. Available from: http://wviz.ideastream.org/news/rock-and-roll-hall-fame-celebrates-20-yearscleveland [Accessed 1 April 2017].

Waitt, G. and Duffy, M., 2010. Listening and tourism studies. Annals of Tourism Research, 37 (2), 457-477. 